\title{
軟弱粘性土地盤中の砂杭造成について \\ INSTALLATION MECHANISMS OF SAND PILES \\ IN SOFT CLAYEY SUBSOILS
}

榎明絜*

By Meiketsu ENOKI

\section{1. まえがき}

サンドドレーン工法やサンドコンパクションパイル工 法などの砂杭を用いた工法は，軟弱地盤改良の代表的工 法として，世界的に広く普及している．日本に扔ける砂 杭工法の実績は，ある専門業者の実績から控え目に推定 しても，毎年 500 件以上の工事で， 1300 万 $\mathrm{m}$ 以上の 砂杭によって 400 万 $\mathrm{m}^{2}$ 以上の軟弱地盤が改良されてい ると見積られる．また，材料の砂についても，現在日本 で生産されている骨材としての砂1) (海砂・山砂・川砂) の $10 \%$ 以上が砂杭工法に関連して用いられているほど である。

砂杭工法のこのような隆盛の技術的背景としては, Barron $^{2)}$ のサンドドレーン理論に代表される各種の理論 的研究の発展や, 各地の工事結果の集積に加えて, 大型 化あるいは強力化されて施工領域を広げていった施工機 械の進歩も忘れることができない．

しかしながら，これら砂杭工法の現場的・実用的な意 味での効果の有無については，いまだに多くの議論が行 われている．たとえば，サンドドレーン工法の圧密促進 効果についての議論 ${ }^{3)}$ においては，非常に効果があった というものから，まったく効果がなかったといらものま での多くの実測データが示されており, 各種の解釈が加 えられてはいるものの，読者を混乱に陥れざるを得な い.このような議論の内容は, 室町・渡辺 ${ }^{4)}$ の分類を参 考にして, (1) 土質データや観測データの信頼性, (2) 解 析理論の妥当性, (3) 施工の信頼性, (4) 効果の判定法, に分類できる.

ところでここれらの項目中，ほとんど調べられていな いのが, (3) 施工の信頼性（砂杭の径, 連続性, 配置な ぞが設計どおり施工されたか) である。すなわち，従 来, 砂杭の品質は, 砂杭の中心で標準貫入試験を行い,

\footnotetext{
* 正会員 工修 愛媛大学助手 工学部海洋工学科
}

$N$ 値や採取試料から判定しているが，砂杭とボーリング 孔の相対的傾斜を考えれば，砂杭が長いほど調查結果が 実際より悪くなりがちなのは当然である。そしてこの調 查も，全数検查には程遠く，統計的に無意味に近いほど 少数しか行われないのが普通である。

本研究は, この砂杭施工の信頼性に注目し, 従来あま り重要視されなかった施工記録（砂杭施工用マンドレル 下端の深度やマンドレル内の砂量などの経時変化の記 録）を解析して，砂杭の品質の良否を判断するととも に，砂杭施工のメカニズム（確実に施工するには, どの ような力関係を満足する必要があるか）を明確化しよう とするものである.これによって，信頼性のある施工や 生産性の向上，あるいは施工機械の合理化，さらには大 深度施工のような施工領域の扡大などの可能性が生まれ るであろう．ただし，ここでは研究対象として，起振機 を用いた打込み式閉端マンドレル方式（排除型の砂杭造 成法）による沖積粘性地盤土での施工を取り上げた。こ の理由は，この方式が現在最も一般的な方式であり ${ }^{5)}$, 現場実験を主にして研究する関係上，この対象以外では 十分な実験ができなかったためである.

\section{2. 砂杭施工の概要と砂杭の品質の判定}

\section{(1) 施 工機 械}

陸上用のマンドレル打込み方式の砂杭施工機の一例を Fig. 1 に示す. マンドレル上端には, 打込み用の起振 機と砂供給用のホッパーが備えられる。下端には，打込 み中に土がマンドレル内に侵入せぬよう，開閉蓋をつけ ることもあるが，少量の砂をあらかじめ入れておくこと で杭の閉塞と同じ効果をあげ，蓋の代用とすることも多 い. マンドレル内は通常 $7 \mathrm{kgf} / \mathrm{cm}^{2}(686 \mathrm{kPa})$ 程度まで 圧気するので，ホッパー下部には密閉できる弁が付属し ている．砂供給用の昇降するバケットを使わないで，マ 


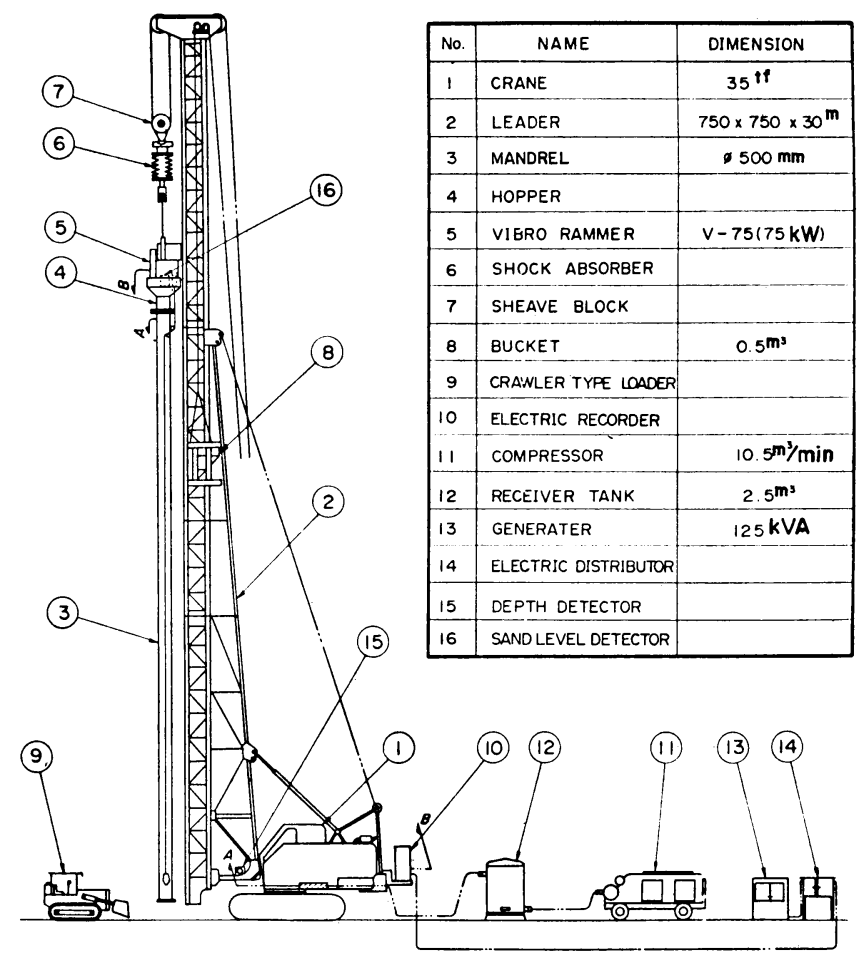

Fig. 1 Sand pile installation equipment on land.

ンドレルを打ち込んでホッパーが地表面近くに降りたと きに，ローダーから直接砂を入れることもある. マンド レルの直径は $40 \sim 100 \mathrm{~cm}$, 長さは最大 $60 \mathrm{~m}$ 程度であ る.なお，海上施工の場合も，台船にすえ付けた同様の 機械を用いる. 砂杭長は，10〜30 m の場合が多いが, 現在は最長 $50 \mathrm{~m}$ 程度までの施工実績がみられる.

\section{（2）施 工手順}

砂杭施工の手順の一例を Fig. 2 に示す. マンドレル に自然含水状態（含水比 $w=5 \sim 10 \%$ ）の砂を少量入れ たのち，地盤へ打ち込む（a). 所定深度に達したら，さ らに砂を入れる (b). マンドレル内を圧気し，マンドレ ルを引き抜く (c). この際, マン ドレル下端から地盤内へ砂が排出 され，砂杭ができる. 普通のサン ドドレーンの施工はこの工程で終 わるが, マンドレル断面積の 2 3 倍の締め固めた砂杭を造るサン ドコンパクションパイルの場合に は，(c) で 2 3 m 引き抜いたの ち, (d) のように再びマンドレル を 1〜2 $\mathrm{m}$ 再打込みし, (c) と (d) の工程を繰り返して砂杭を造るこ ともある。

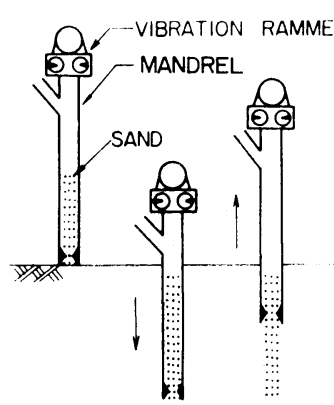

(a) (b)

(C)

(d)

Fig. 2 Procedure to form a sand pile. は, すると，

いずれの場合でも，(c) の工程が大切で， この工程で砂が地盤内へ十分に排出されない と，砂杭が切れたり細ることになるので，本 研究では（c）の工程を中心に考える.

\section{（3）砂杭施工の判定指標}

現在用いられている設計法 ${ }^{6}$,7) から考える と, 砂杭に要求される品質としては, サンド ドレーン工法では, まず鉛直方向の連続性, 次に砂杭配置, 杭径であり, サンドコンパク ションパイル工法では，それらに砂杭強度に 関する品質 (内部摩擦角 $\phi$ あるいは間隚比 $e$ など）が追加される．また，最近よく用いら れる強制置換工法 (大径の砂杭を密接して造 成し, 軟弱地盤の強制的な置換を行う工法) では, 杭径 (砂量) が最重要視される.

したがって, 共通して杭径（あるいは杭断 面積）に対する要求が強く, 鉛直方向の連続 性も杭径が零でないことと同義と考えれば, 杭径あるいは杭断面積を一つの基準として砂 杭施工の良否を考えることができる．

ところで, Fig. 2 (c) のマンドレル引抜き 工程において造られる砂杭の断面積 $A_{s}$ は, Fig. 3 に示すように, マンドレル内の砂の表面のマン ドレル下端からの高さ $S L$ と, マンドレル下端の深度 $z$ を常時測定することによって推定できる. すなわち, 微少時間 $d t$ におけるマンドレル引抜き長 $d z$, 砂面降 下高 $d S L$, その間に造成された砂杭断面積 $A_{s}$ の間に

$$
A_{s}=\frac{r_{1}}{r_{2}} \cdot \frac{d S L}{d z} \cdot A_{m i}
$$

が成立する. ここで, $A_{m i}$ はマンドレルの内断面積, $r_{1}, r_{2}$ はそれぞれマンドレル内と砂杭での砂の単位体積 重量である.そして, 次式のように排出効率 $\eta$ を定義

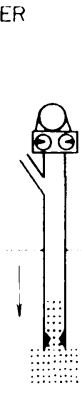

Fig. 3 Estimation of sectional
aea of a sand pile.


$r_{1} / r_{2}=1$ の簡単な場合には, $\eta=1$ なら マンドレルと同 じ断面積の砂杭ができ, $\eta=0$ なら 砂杭はこの深度で切 れていることになる.すなわち, ク は砂杭の施工の良否 を表わす指標と考えられる.たとえば, サンドドレーン では普通砂杭径と同径のマンドレルを用いるので, 施工 中, 常に $\eta \geqq 1$ を維持することが必要である.

なお, $\eta$ を求める場合, ある有限の引抜き長 $\Delta z$ と, その間の砂面降下高 $\Delta S L$ を用いるのが実用的である. $\Delta z$ としては 1 3 m がよいが, 再打込み工程のあるサ ンドコンパクションパイル工法では，1回の引抜き工程 全長（2〜3 m) をとると便利である.

\section{(4) 砂杭施工に関する測定 ${ }^{8)}$}

砂杭の施工状態を調べ, 砂杭の良否を表わす前述の排 出効率 クとの関連を調べるには, 施工中連続して 各種 の測定・記録を行う必要がある. Fig. 4 にその一例を 示す.

この場合, マンドレル下端深度 $z$ は, マンドレルに定 着したワイヤーにより深度検出器のプーリーを回転させ て測定する. 砂面高さ $S L$ は, 電極錘と砂面との接触 状態を絶縁ワイヤーの巻取り・巻出しにフィードバック するサーボ機構により，電極錘を砂面に追従させて，ワ イヤー長から測定する.このほか, マンドレル内の圧気 圧 $p$, 起振機の消費電力, 振動加速度 ${ }^{9}$, マンドレルを

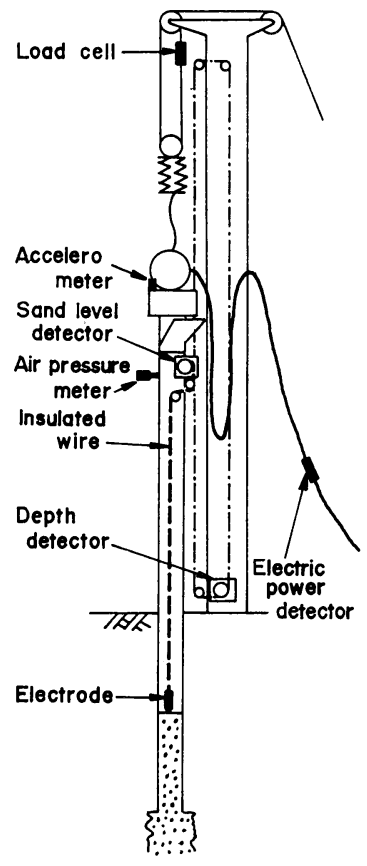

Fig. 4

Measurements on installation of sand piles.

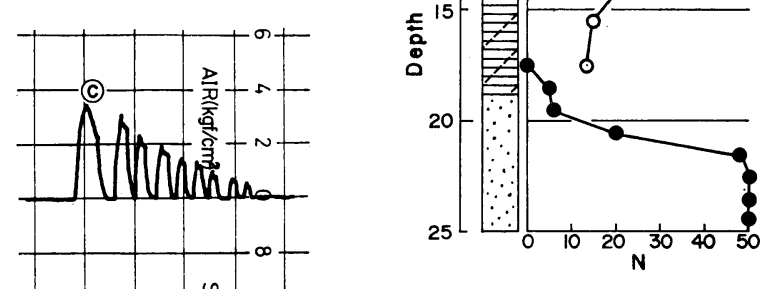

(a)

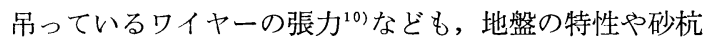
の施工状態に関係する測定項目である.

Fig. 5 に再打込み工程のあるサンドコンパクション パイル工法での, マンドレル下端深度 $z$, 砂面高さ $S L$, マンドレル内圧気圧 $p$ の記録例を示す. 図中の (a) (d) の各工程は, Fig. 2 と対応している.

\section{3. 現場データの解析と施エに関する仮説}

\section{（1）現場施エデータの解析}

砂杭施工は，普通，Fig. 6 (a)，(b) に示すような， ほぼ正規圧密状態の粘性土地盤に対して，Fig. 7 に示 すような 粒度の砂を自然含水状態 $\left(D_{10}=0.1 \mathrm{~mm}\right.$ で 自 然含水比 $w_{n}=10 \sim 17 \%, D_{10}=0.5 \mathrm{~mm}$ で $w_{n}=3 \sim 7 \%$ )

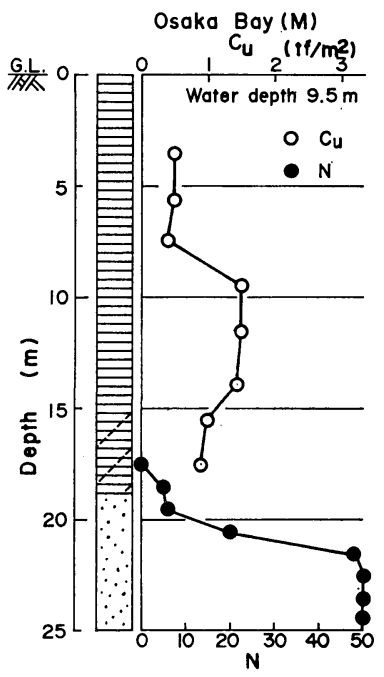

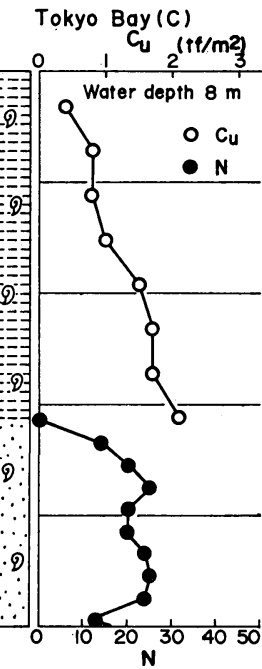

$1 \uparrow f / \mathrm{m}^{2}=9.8 \mathrm{kPd}$

(b)
Fig. 6 Profiles of subsoils where sand piles are installed.

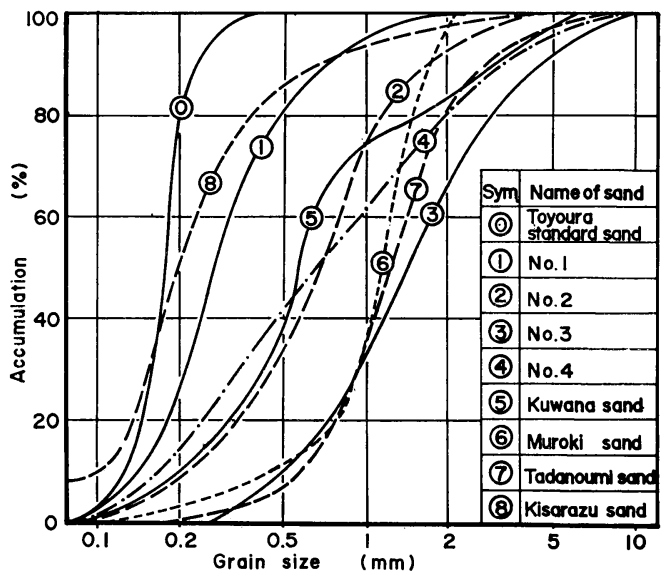

Fig. 7 Grading of sands for sand piles. 
で用いて行われる.このような一般的な条件下で, マン ドレル再打込み工程のある施工法の Fig. 2 (c) のマン ドレル引抜き工程について, 排出効率 $\eta$ を指標として, 現場施工データを調べてみた。 その結果， $\eta$ と直接的な 相関のみられる施工状態は, 施工記録例 Fig. 5 からも 明らかな深度 $z$ と引抜き工程のマンドレル 内圧気圧 $p$ のみで, マンドレル内の砂量 $S L$ やマンドレル下端構 造 (開閉蓋の有無など) とはほとんど相関がみられない.

この相関をさらに定量的に調べるため，Fig. 6 (a) の海底地盤で, Fig. 7 の忠の海産粗砂を用いたマンド レル再打込み工程のある施工法の実験施工を行った。こ の実験施工では，個々の工程を分離して緩速に行い，圧 気はマンドレル引抜きょり早くから与え，引抜き中もほ ぼ一定圧となるよう制御している.

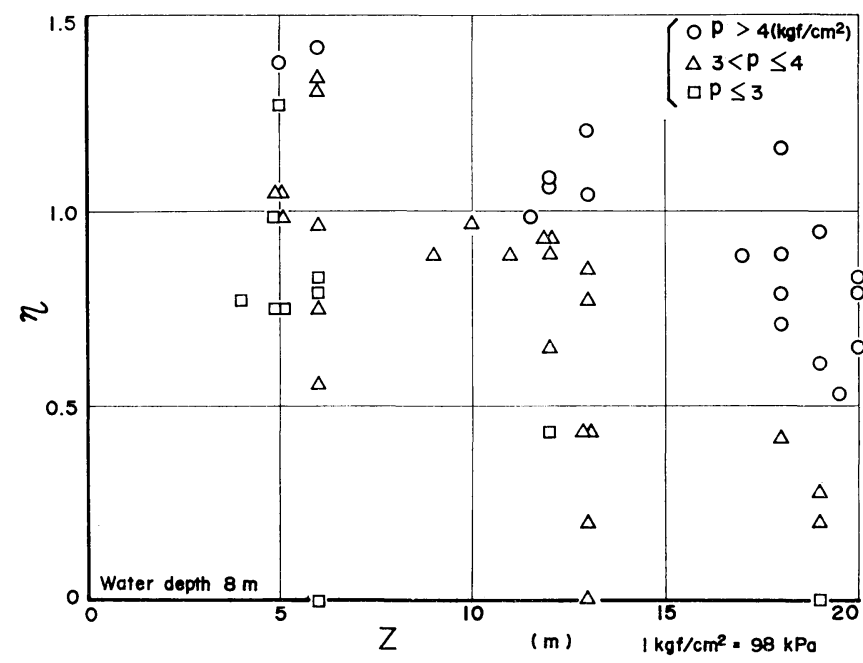

Fig. 8 Index $\eta$ vs. depth of mandrel $z$ obtained by field experiments.
実験結果として得られた $\eta$ と $z, p$ の関係を, $p$ お よび zをパラメーターとしてそれぞれ Fig. 8, Fig. 9 に示す.一定深度なら圧気圧の大きいほど, 一定圧気圧 なら深度の小さいほど，砂がよく排出されている．特に Fig. 9 では， $\eta=1$ とするのに必要な圧気圧が，それぞ れの深度の全応力で求めた土被り圧を少し上回る程度の 圧力であること, また $1 \mathrm{kgf} / \mathrm{cm}^{2}(98 \mathrm{kPa})$ 程度の小さな $p$ の変化が $\eta$ には大きく影響することがわかる．また， 同じ実験施工で，マンドレル内を圧気し，マンドレル内 砂面上部の空間が一定圧になってからマンドレルを引き 抜くまでの圧気時間 $t$ の影響を， $z=18 \sim 20 \mathrm{~m}$ で調べ たものが Fig. 10 である.

$p$ が大きい場合, マンドレル上部空閒が一定圧に達す るのに数十秒かかるため, 砂に圧気が作用した正味時間 は図中の $t$ より長いと考えるべきだが，圧気 時間が長いほど砂の排出がよくなることは明 らかである。

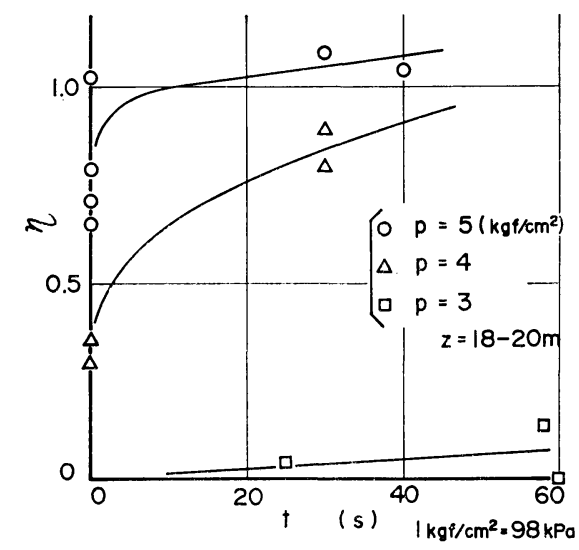

Fig. 10 Index $\eta_{\text {vs. }}$ pressured time $t$ with air.

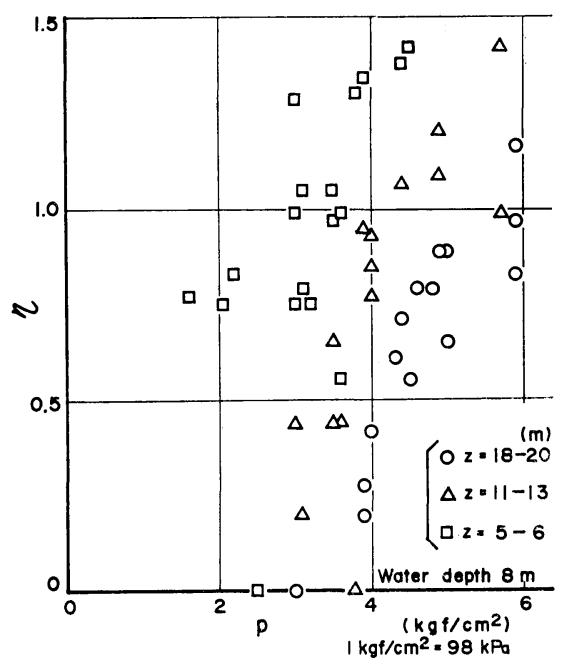

Fig. 9 Index $\eta$ vs. air pressure $p$ obtained by field experiments.

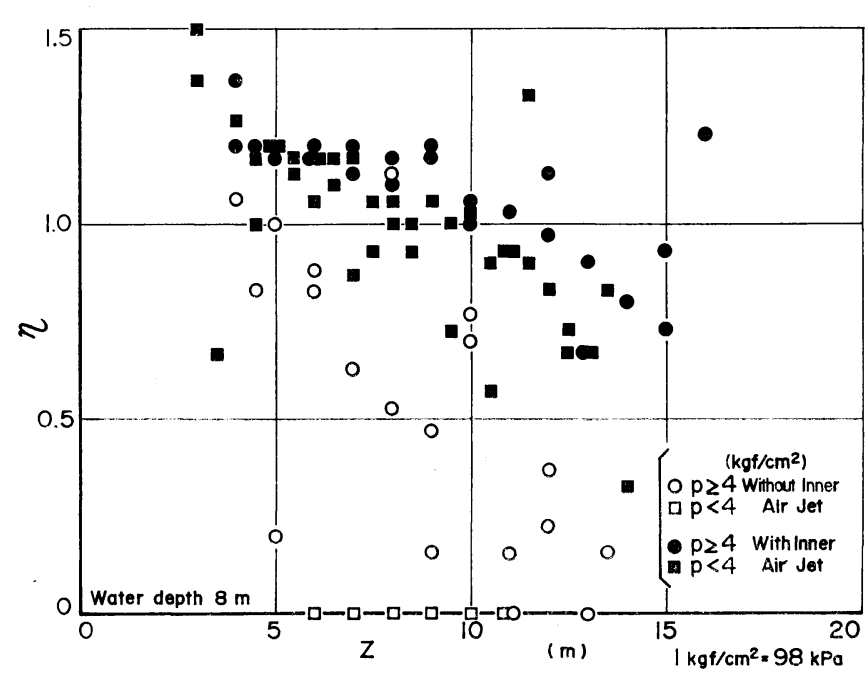

Fig. 11 Index $\gamma$ vs. depth of mandrel $z$ in the case of fine sand. 
一方，同様の実験施工を，Fig. 6 (b) の地盤で，今度は Fig. 7 の木 更津産細砂を用いて行った.この結 果を Fig. 8 と同様に整理してFig. 11 に示す. 細砂の場合も粗砂の場 合と同じ傾向がみられるものの，砂 の排出が全般に悪い.

このように排出の悪い細砂を使う 施工では, 従来から経験的に「放ジ エット」と称する Fig. 12 に示す ような, マンドレル下端付近に設け たノズルから圧気を加える装置が用 いられる。この内ジェットをマン ドレル引抜き中に併用した結果を

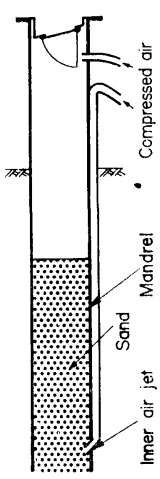

Fig. 12

Mandrel and inner air jet.
Fig. 11 亿あわせて示す. 砂排出の良化が顕著にみられ る.さらに，マンドレル引抜き前から内ジェットを用い た場合の内ジェットによる圧気時間の影響を調べると

Fig. 13 が得られ，Fig.10 と同じ傾向を示す.

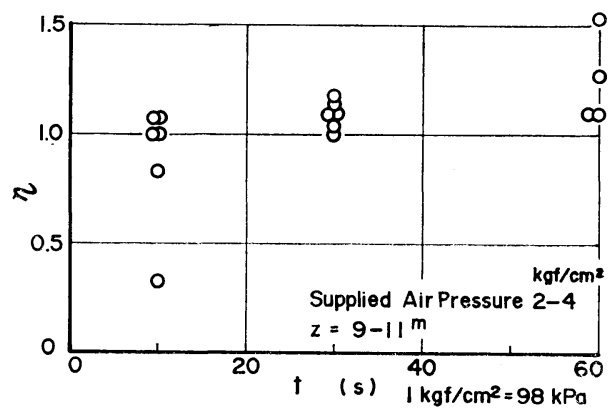

Fig. 13 Index $\eta$ vs. pressured time $t$ by inner air jet.

なお，次のような事項も，多くの施工現場で観察され る.

1）陸上施工の場合のごく浅部（マンドレルを引き抜 いても孔壁が自立するような深さ）を除いて，圧気なし ではマンドレルを引き抜いても砂はをったく排出されな い. 逆に高圧の圧気を行うと, マンドレルを引き抜かな いでも砂は排出される.

2）地表でマンドレル内に砂を詰め，マンドレルを空 中に吊り上げると，圧気なしでも砂が排出される（この 場合, マンドレルに振動を与えた方が排出が円滑であ る).

\section{（2）マンドレルから地中への砂排出に関する仮説}

前述した現場施工データを無理なく説明するには, 「マンドレル引抜きによって生じた空洞を，砂中を透気 してきた圧気が維持し，その空洞内に砂が流下・排出さ れ砂杭ができる」という仮説を考えるのが自然であろ 5 .

この仮説が成立するためには，次の 4 項目が満足され ねばならない。

1）砂が落下・排出されるためには，マンドレル下に 空洞が必要である.

2）ママンドレル内に詰まった砂の重量は，ほとんどが マンドレル壁面との摩擦によって支持され, マンドレル 底部にはほとんど伝達されない。

すなわち, マンドレル下端の忍状態に, マンドレル 内の砂の重量はほとんど寄与せず, もっぱら次項の圧気 圧のみが関係する。

3）圧気圧はマンドレル内の砂を透気してマンドレル 下端に伝達される．粗砂では透気性がよいため伝達が早 いが，細砂では透気性が悪いため伝達に時間がかかる.

このため, 内ジェットのよらにマンドレル下端付近で圧 気を加えて, 伝達時間の短縮を図る必要がある.

4）マンドレル引抜きによって生じた空洞は，そのま までは維持できず，ふさがってしまう．この空洞を維持 するために必要な圧力は, 深いところほど大きい.

このうち，1）は現場観察で証明されているので，他 の項目について, 以下で詳細に検討する.

\section{4. マンドレル内の砂の挙動}

力学的には，これはサイロ内に詰まった粉体の鉛直压 力という形の古典的な問題で, Janssen の式など ${ }^{11}$ が知 られており，類似の問題である開端杭の閉塞効果に関し ても, 山原 ${ }^{12)}$ をばめ多くの研究 ${ }^{13)}$ がなされている.

ここでは, 仮説に関連して, マンドレル内に詰まった 砂の底面圧力についての室内実験 I を行うとともに, 圧 気の効果についての従来の考え方, すなわち圧気は砂を マンドレルから押し抜くといら説明の適否を調べるため に，マンドレル内に詰まった砂を押し抜く圧力について の実験II（室内および現場実験）を行い, 結果に対し て, Janssen の式などに基づ いた考察を加える.

\section{(1) 実 験 概 要 ${ }^{14)}$}

a) 実 験 I

実験装置は Fig. 14 に小 术上らに，鋼管（内径 106 mm）またはテクリルパイブ (内径 40, $101 \mathrm{~mm}$ ) 老湖定 し，一端に管内径とほぼ同径 の底板を付けたロードセルを 置いた。使用砂は Fig. 7 に 示す粒度調整して作成した No. $1 \sim$ No. 4 と豊浦標準砂

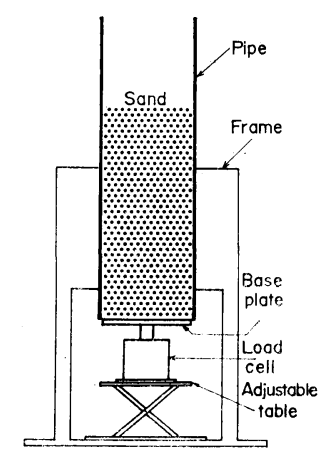

Fig. 14

Test apparatus to measure pressure at the bottom of pipe. 
の 5 種類で, 含水比は標準砂については室乾状態から飽 和状態までの 7 段階で，他の砂は室乾状態で用いた．実 験はパイプ内に砂を入れ，高さ $10 \mathrm{~cm}$ ごとにロードセ ルで底面圧力を求める方法で行った。

b) 実 験 II

地中に打ち込まれたマンドレルから，内部に詰まった 砂を地盤内へ押し抜く場合, マンドレル内の砂柱には, 次の 3 力が作用すると考えられる. 第一は, 砂柱の底面 から上向きに作用する地盤が押す力で，この力はマンド レル下端深度での土被り圧または深い基礎の支持力によ り概略の推定ができる．第二は，砂柱の周面で上向きに 作用するマンドレルとの摩擦力である. 第三は，第一と 第二の力に打ち勝って砂を押し抜くための，砂柱上面か ら下向きに押す力で，従来の考え方では，圧気圧がこの 力を発揮していることになる.この力関係を再現するた め, 室内実験では，Fig. 15 に示す装置を用いた．マン ドレルとして内枠に固定された鋼管（内径 $106 \mathrm{~mm}$ ) を 用いた。

地盤が押す力は，砂柱下部から底板を介して空圧シリ ンダーによって与えた. 砂柱は, 上部から載荷板を介し て油圧シリンダーにより定速で押し抜かれる。それに伴 い，底板は下降し，空圧シリンダーは縮むが，圧力調整 弁により空圧シリンダーの推力は一定に保たれる。これ らの装置全体，すなわち内枠には，起振機（起振力 133 $\operatorname{kgf}(1303.4 \mathrm{~N}), 20 \mathrm{~Hz})$ が取り付けられ，外枠から緩衝 器で吊り下げられているので, 実施工時のような振動下 での砂の押抜き実験もできる. 一方, 現場実験で用いた 装置は，上部に起振機（起振力 $40 \mathrm{tf}(392 \mathrm{kN}), 9.3 \mathrm{~Hz}$ ) を備えた鋼管下部に，Fig. 16 に示すような鋼管断面積

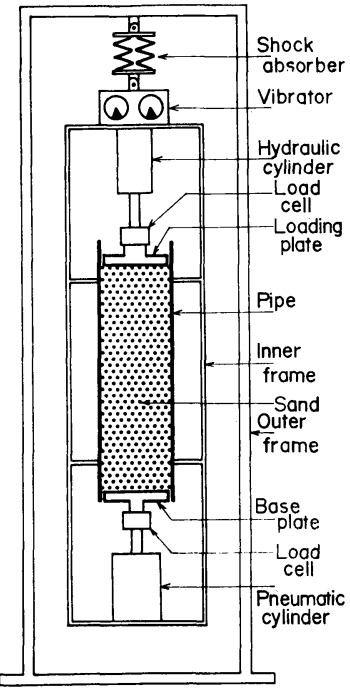

Fig. 15

Test apparatus to punch sand from pipe.
の約 $1 / 8$ の載荷板を付け た油圧シリンダー 4 本を
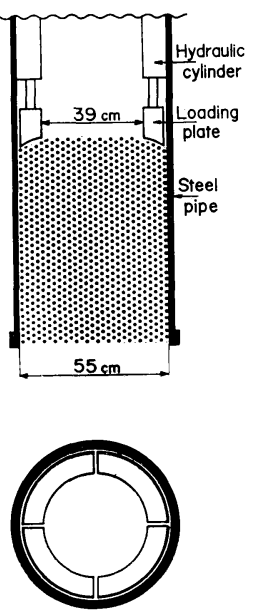

Fig. 16

Field test apparatus to punch sand from pipe.
内蔵している．鋼管を地表面に載せて，載荷板下部に砂 を入れたのち，油圧シリンダーで押抜き力を与えると， 鋼管が持ち上がることによって，相対的に砂が押し抜か れる.したがって，この場合は，砂柱の下部から鋼管の 全重量（起振機なども含む）に相当する力が作用してい る状態で，砂柱を押し抜いたことになる．使用砂は，

Fig. 7 に示した桑名産, 室木産の砂のほかに, 粗い鉱 砕 $\left(D_{10}=2.5, D_{60}=14.5 \mathrm{~mm}\right)$ を自然含水状態で用い た.

\section{(2) 実験結果と考察}

実験 I の結果を Fig. 17，18 に示す.これらの図は, 縦軸として底面圧力 $p_{x}$ を砂の単位体積重量 $\gamma_{t}$ で除し た換算高さをとり，横軸に実際の砂の高さをとってい る. 図中の破線は, 管径 $D=101 \mathrm{~mm}$ の場合の，砂の静 止土圧係数 $k$ と砂と壁面の摩擦係数 $\mu$ の積を数通り変 えて求めた次の Janssen の式による 底面圧力を表わし ている.

$$
\frac{p_{x}}{r_{t}}=\frac{D}{4 \mu k}\left(1-e^{-\frac{4 \mu k}{D} x}\right)
$$

Fig. 17 から, 底面圧力 $p_{x}$ はほぼ式 (3) で表わせ， 砂や管の種類で少し異なるが, 砂の高さ $x$ が管径の数倍 以上ではあまり増加しないことが明らかである。また，

Fig. 18 から, 含水比が高くなるに従い, 底面圧力はい ったん低下するが，その後は増加し，飽和砂ではこの実 験の $x$ の範囲ではほぼ全自重となっている，圧力低下の 理由は，適当な含水比で見脚けの粘着力が生じたためと 考えられる. また, 飽和の場合には浮力によって有効応 力が減り, 結果的に管壁での摩擦抵抗が減るためと考え

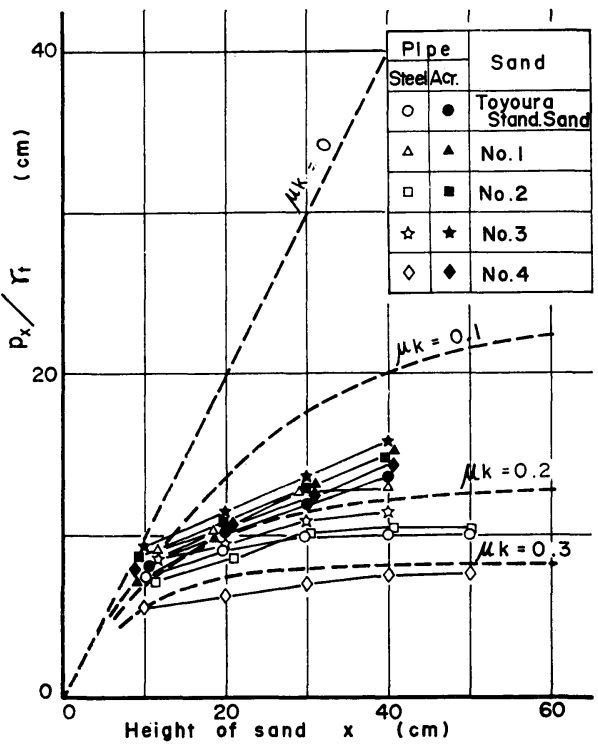

Fig. 17 Equivalent height of bottom pressure vs. height of sand. 


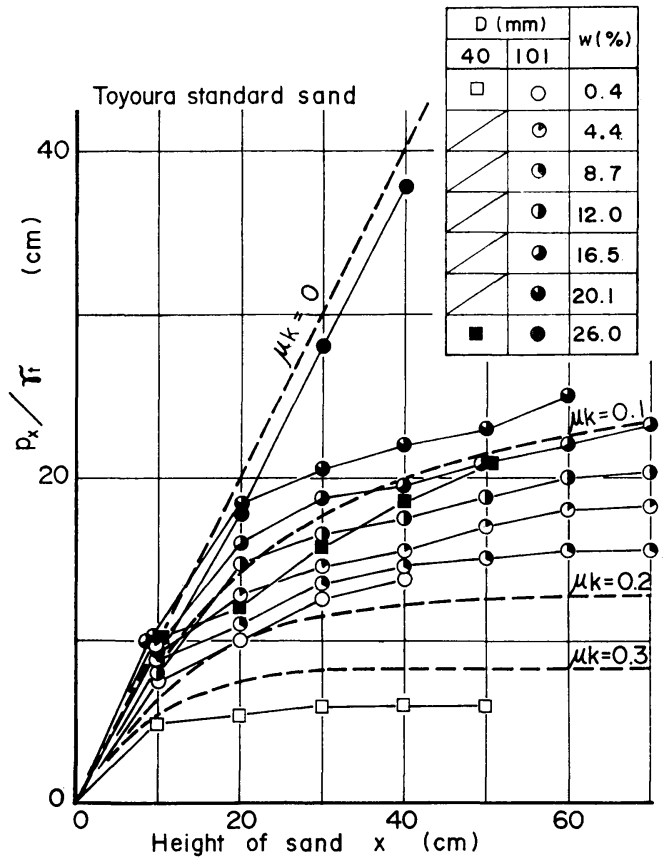

Fig. 18 Variation of bottom pressure $p_{x}$ with water content $w$.

\section{られる。}

なおう，Fig. 14 の装置全体を鉛直方向に振動させ，動 的な底面圧力を調べると, 振動加速度の増加とともに振 幅も増加するが, 平均的には静的な底面圧力と同様の結 果が得られた. また, どの実験においても, 底板をパイ プ下端より下げると, 底面圧力が少し低下するととも に, 底板とパイプの透き間から砂が漏れるのが観察され た.

実験 II の室内実験結果を Fig. 19 に，現場実験結果 を Fig. 20 に示す. ともに, 縦軸に押抜き圧力 $p_{0}$, 横 軸に砂の高さ $x$ をとり, 下端からの反力 $p_{b}$ や振動の 有無, 砂の種類をパラメーターとしている. 図中の破線 は, Janssen の式と同様に導いた次式を表わしている.

$$
p_{0}=\frac{D r_{t}}{4 \mu k}-\left(\frac{D r_{t}}{4 \mu k}-p_{b}\right) e^{\frac{4 \mu k}{D} x}
$$

両図から，押抜き圧力 $p_{0}$ はほぼ式 (4) で表わすこと ができ, 砂の高さ $x$ が零から管径の数倍となるに従い, $p_{0}$ は下端反力 $p_{b}$ と同じ圧力からその数十倍となるこ と, 静的でも動的でもほぼ同じ挙動を示すことが明らか である。

\section{（3）実施エにおけるマンドレル内の砂の挙動に ついて}

以上の実験結果から，実施工に拈ける 直径 $40 \sim 100$ $\mathrm{cm}$ のマンドレル内に $10 \sim 50 \mathrm{~m}$ 詰まった砂の挙動は, 次のように考えられる.

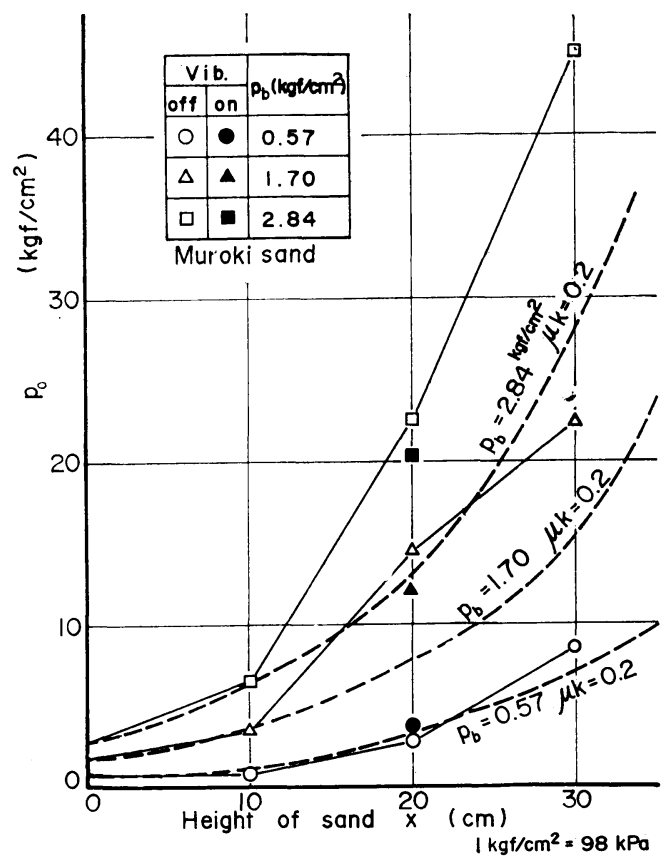

Fig. 19 Punching pressure $p_{0}$ vs. height of sand $x$ obtained by laboratory test.

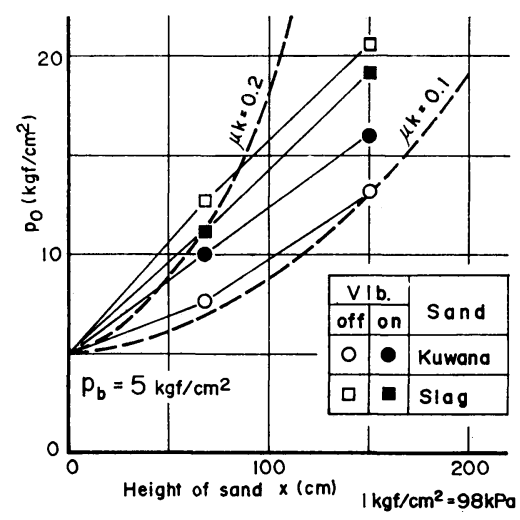

Fig. 20 Punching pressure $p_{0}$ vs. height of sand $x$ obtained by field test.

1）マンドレル底の地盤に作用する砂の鉛直圧力は， 普通の自然含水状態の砂では非常に小さく無視し得る が，飽和砂ではかなり大きく，少なくとも同じ高さの水 による水圧以上である.

2）マンドレル下部に空間があれば，マンドレル内の 砂悇々に落下し，排出される（実験中の観察より）.

3）マンドレル底の地盤からいくらかの反力が作用す る状態で, マンドレルから自然含水比の砂を押し抜くに は, 非常に大きな圧力を要し, 事実上不可能に近い.

したがって，前述の仮説のための項目 1)，2）は妥当 と考えられるとともに，圧気が砂をマンドレルから押し 抜くという従来の説明は否定される. 


\section{5. マンドレル下端での原位置土圧}

軟弱粘性上地盤中に打ち込んだ杭を引き拔くと，孔が 閉じてしまい，孔を維持するには，泥水などを用いなけ ればならないことは，現場でよく観察されることであ る。また，室内でも，閉端マンドレルを打ち込み，それ を引き抜くときには, マンドレル下端にサクションを生 じ，孔径が小さくなることが知られている ${ }^{5}$.

ここでは，マンドレル下の空洞を維持あるいは拡大す るのに必要な力を現場実験で調べるとともに，塑性論な ぞから若干の考察を加える.

\section{（1） 現場実験の概要 ${ }^{15}$}

現場実験は，Fig. 6 に示した地盤およびそれらと非 常によく似た地盤で行った. いずれも水哚 4 9.5 m の 海底のほぼ正規圧密状態の粘性土地盤である．実験に は，Fig. 1 と同じ構造の海上型砂杭施工機を用い, Fig. 4 に示した測定装置を備えた直径 $50 \sim 100 \mathrm{~cm}$ の マンドレルを用いた。

実験方法は，マンドレル內に地盤の土が逆流しないよ らにしてマンドレルを所定深度まで打ち込む。ここでマ
から，次式に示す全念力での Rankine の主働および受 働土圧を求めたものである.

$$
\begin{aligned}
& p_{a}=\left(r_{w} z_{w}+r_{t} z\right)-2 c_{u} \\
& p_{p}=\left(r_{w} z_{w}+r_{t} z\right)+2 c_{u}
\end{aligned}
$$

ここで， $z_{w}$ は水深， $z$ は海底面からの深度である. 奏 測值と Rankine 土圧は比較的よく一致している.

このような粘性土地盤中の空洞という三次元軸対称塑 性問題は，自由面である地表面を考慮した形では完全に 解かれていないが，無限地盤内の球形空洞あるいは円筒 形空洞の弾塑性解に土被り圧を重ね合わせた形では解が 得られている ${ }^{16), 17)}$. そして空洞拡大に必要な圧力は, 解法上当然であるが， Rankine 土圧と類似の形の土被 り圧とせん断強度などの関数として与えられている.し かし Fig. 21 から，実用上は，このような三次元問題 であっても，二次元問題の Rankine 土圧を用いること が許されると考えられる.

なお，現場実験での土圧は，排除型のマンドレルによ り地盤に擋乱を与えて測定しているため，非排除型の場 合とは少し異なる可能性もあると考えられる。

\section{（3）実施エで必要なマンドレル下端での圧カ}

以上の実験結果から，マンドレル引抜きによって生じ
ンドレル内に圧気を加えるかまたは水を入れ ることによって，マンドレル下端に空気圧ま

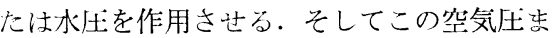
たは水圧を上げて，これらがマンドレル外に 漏れ始める，すなわちマンドレル下部の空洞 が広がるときの圧力を地盤の受働土圧, 逆に 圧力を下げて，マンドレル内に地盤の土が逆 流し始める圧力を主働土圧とした，な掞，実 際には，マンドレルを所定深度で停止して測 定するのでなく, 打ち込みつつ, あるいは引 き抜きつつ測定している.

この測定方法は, いわば地盤内で風船をふ くらましたり縮めたりするもので，プレシオ メーターの原理に近いものである. なお，こ こでいう土圧とは, 粘性土地盤での施工とい ら短時間 (非排水)の問題を対象とするので， 全応力の土压を指すことは当然である.

\section{（2）実験結果と考察}

測定された主働・受働士厷を，Fig. $21 に$ 亦す・どの現場でも，主働・受働土圧は深さ とともに増加しており，また水深の影響も明 らかである。

図中の破線と実線は，それぞれ地盤の非排 水せん断強度 $c_{u}\left(=q_{u} / 2\right)$ と単位体積重量 $r_{t}$
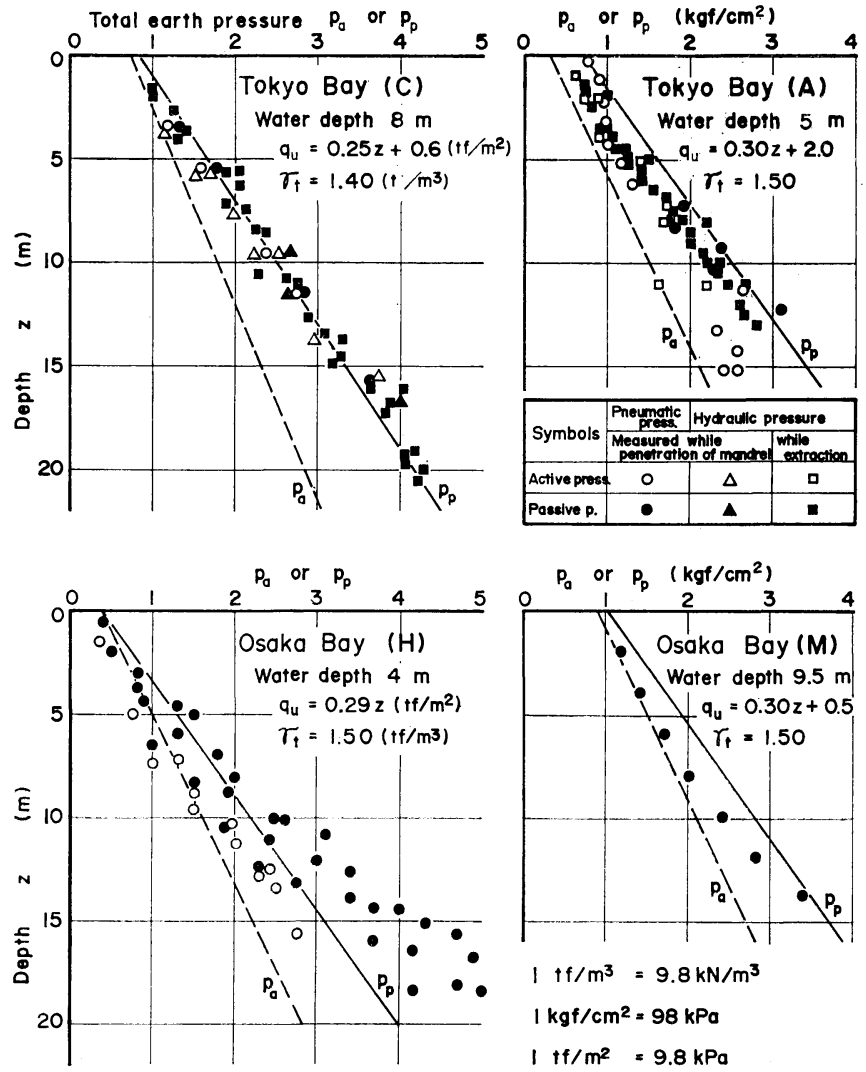

Fig. 21 In-situ earth pressure $p_{a}$ and $p_{p}$. 
た空洞の維持あるい梳拡大に関して，次の結論を得る。

1) 空洞の維持には, マンドレル下端で式 (5) の主偅 土圧 $p_{a}$ 以上の圧力（全応力）が作用することが必要で ある。

2) 圧力をさらに式（6）の受衝士圧 $p_{p}$ まで上げる と，マンドレルの径以上の空洞をつくることもできる. また，マンドレルを引き拢かないで空洞をつくることも できる.

したがって，前述の仮説のための項目 4）注妥当と考 えられる。

\section{6. マンドレル内の砂中の透気}

前述の仮説のための項目 3) は, 定性的には容易に想 像できることであるが，圧気の效果をこのように限定す るには, 圧気压とその伝達時間が実施工で用いられる機 械の能力や施工サイクルタイムと矛盾しないかどらかを 調べる必要がある.

ところで, マンドレル下端で必要な圧気圧は, 式 (5), (6) 汃ら, 通常の施工ではたかだか数 $\mathrm{kgf} / \mathrm{cm}^{2}\left(1 \mathrm{kgf} / \mathrm{cm}^{2}\right.$ $=98 \mathrm{kPa})$ となり, 現実に用いられるコンプレッサーの 能力 (普通, 最高吐出压 $7 \mathrm{kgf} / \mathrm{cm}^{2}(686 \mathrm{kPa})$ ) 以下とな るので, 矛盾はない，ここでは，伝達時間に注目して， マンドレル内の砂中の透気について調べてみる.

\section{(1) 透気理論について}

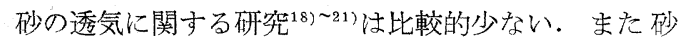
杭施工の場合には, 簡単な一次元透気で市るが, 圧力 勾配が大きいため, 空気の圧縮性や乱流の発生を考慮す る必要がある。

砂を細管の並列集合と考光る場合の層流条件は, 普 通, 次式のレイノルズ数 $R_{e}$ で与えられる.

$$
R_{e}=\frac{d \cdot v \cdot \rho}{\mu}<2000
$$

ここで， $d$ は管径， $v$ は管内の平均流速， $\rho$ は流体の 密度, $\mu$ 注粘性係数である.

砂の透気の場合，空気は砂との熱交換によって断熱よ りは等温状態で変化すると考えられる. そして, 空気の 場合， $\mu$ は圧力には関係せず，通常の温度範囲では約 $18 \mu \mathrm{Pa} \cdot \mathrm{s}$ としてよい. $\rho$ は, 圧力 $p$ に比例するが, 常 温・大気圧 $p_{\mathrm{atm}}$ で $1.2 \mathrm{~kg} / \mathrm{m}^{3}$ なので, 式 (7) は次の ようになる。

$$
d \cdot v \cdot \frac{p}{p_{\text {at } \mathrm{m}}}<300\left(\mathrm{~cm}^{2} / \mathrm{s}\right)
$$

乱流の場合, 体積速度 $v$ と圧力勾配 $\partial p / \partial x$ の間に,

$$
v^{2}=\mathrm{const} \cdot \frac{d}{\rho} \cdot \frac{\partial p}{\partial x}
$$

が成立すると考えられ，さらに空気の状態方程式を考慮
すると，砂中の一次元非定常流に対して次式が得られ る.

$$
\frac{\partial p}{\partial t}=k_{t} \frac{\partial}{\partial x}\left(p \frac{\partial p}{\partial x}\right)^{1 / 2}
$$

ここで， $k_{t}$ ほ乱流の場合の透気係数である.

また，層流の場合には，速度と圧力勾配の関係とし て，次に示す体積速度 $v$ 亿関する Darcy 則に基ぶく式 (11) と，質量速度 $\partial m / \partial t$ に関する Fick 則に基づく式 (12)の 2 通りが考えられる.

Darcy 則 $v=k_{D} \frac{\partial p}{\partial x}$

Fick 則 $\left.\frac{\partial m}{\partial t}=I\right) \frac{\partial p}{\partial x}$

それぞれから, 空気の状態方程式を考慮して, 式 (13)，(14）の上らな一次元非定常透気方程式が導かれ $ろ^{21)}$.

Darcy 則 $\frac{\partial p}{\partial t}=k_{D} \frac{\partial}{\partial x}\left(p \frac{\partial p}{\partial x}\right)$

Fick 則 $\frac{\partial p}{\partial t}=k_{F} \frac{\partial^{2} p}{\partial x^{2}}$

ここで, $k_{D}, k_{F}$ はそれぞれ Darcy 則, Fick 則に基づ く透気係数で, $k_{F}=D R \theta / w(R:$ ガス定数, $\theta$ : 絶対温 度, $w$ : 分子量) である.

Fick 則による非定常透気方程式 (14) は, Terzaghi の圧密方程式と同じで，容易に解けるが，乱流則による 式（10）抢よびDarcy 則による式（13）は非線形で解 析解を得ることが困難である.

また，両端の圧力を $p_{1}, p_{2}$ とした長さ $l$ の砂柱の定 常透気について各式を解くと, 乱流則および Darcy 則 で注,

$$
p=\sqrt{\left(1-\frac{x}{l}\right) p_{1}{ }^{2}+\frac{x}{l} p_{2}{ }^{2}}
$$

と, $p$ が $x$ に対し曲線となり,一方, Fick 則では,

$$
p=\left(1-\frac{x}{l}\right) p_{1}+\frac{x}{l} p_{2}
$$

と, $p$ が $x$ に対し直線的に変化する.

\section{(2) 透気実験}

a) 実験 $I^{22)}$

圧力勾配の大きい場合の透気現象の支配則を確認する 目的で, Fig. 22 の実験装置により, 室乾状態 $(w<1$ $\%$ ）の忠の海産の粗砂を $e \approx 0.7$ 亿詰めて, 室内実験を 行った. 実験は, ます管下端を開放して定常状態での空 気圧分布および解放側での流量を測定した. 次に管下端 を閉じて，上端に圧気を作用させた瞬間からの圧力の伝 達状態, すなうち非定常透気試験を行った.

b) 実 験 II

圧力勾配 $\Delta p / \Delta x$ や空気間隙比 $e_{a}$ の透気係数 $k_{D}$ に 対する影響, 透水係数 $k$ と透気係数 $k_{D}$ の関係を調べ 


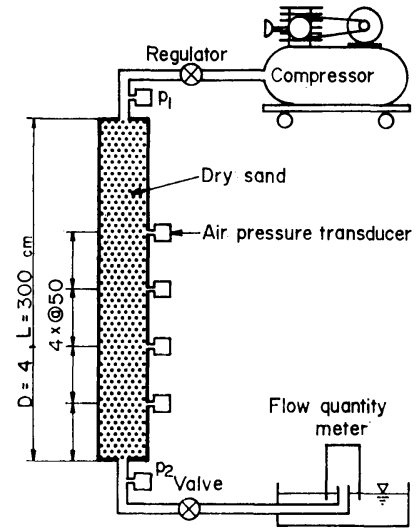

Fig. 22 Apparatus to test permeability of air through sand.

る目的で, Fig. 22 と類似の高さ $150 \mathrm{~cm}$, 直径 $5.3 \mathrm{~cm}$ の透気容器による定常透気試験を行った. 試料として は， $w=5.5 \%$ の忠の海産粗砂， $w=9.1 \%$ の木更津産 細砂, $w=6.3 \%$ のマ开土 $\left(D_{10}=0.23, D_{60}=1.4 \mathrm{~mm}\right)$ を用いた。

\section{(3) 実験結果と考察}

\section{a) 定常透気について}

Fig. 23 に実験 I による定常透気の圧力分布を示す. 図中に，圧力分布が曲線となる式（15）の理論值をあわ せて示したが, Fick 則よりも Darcy 則や乱流則の方が 適合性のよいことは明らかである。また，解放側の透気 速度は, $p_{1}=3.3,2.4 \mathrm{kgf} / \mathrm{cm}^{2}(323.4,235.2 \mathrm{kPa})$ に対 し，それぞれ $122,84 \mathrm{~cm} / \mathrm{s}$ で，この程度の圧力勾配で も式（8）加層流と扱ってよいと考えられる.

ところで, Fig. 23 において, 実測值と Darcy 則に よる理論值には少しずれがみられる．この理由は透気係 数 $k_{D}$ が圧力勾配の影響を受けるためではないかと考え

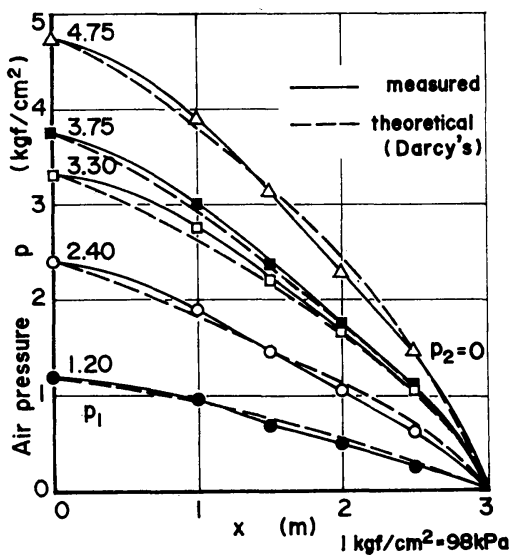

Fig. 23 Air pressure distribution in steady seepage flow of air.
られたため，実験 II を実施した。その結果を Fig. 24 に示す．横軸は，約 $150 \mathrm{~cm}$ の砂柱全体についての見掛 け上の圧力勾配であり，Fig. 23 のデータも砂柱中央高 さの圧力を用いて図に含めた．Fig. 24 から， $k_{D}$ が圧 力勾配 $\Delta p / \Delta x$ の増加とともに低下寸ることが明らか で，前述のずれも定性的に説明できる.

実験 II の結果の Fig. 25 から，透水の場合と同様に， $k_{D}$ は空気間嚐比 $e_{a}$ の増加とともに増加するが, その 值は，空気と水の粘性係数の比較から普通にいわれてい

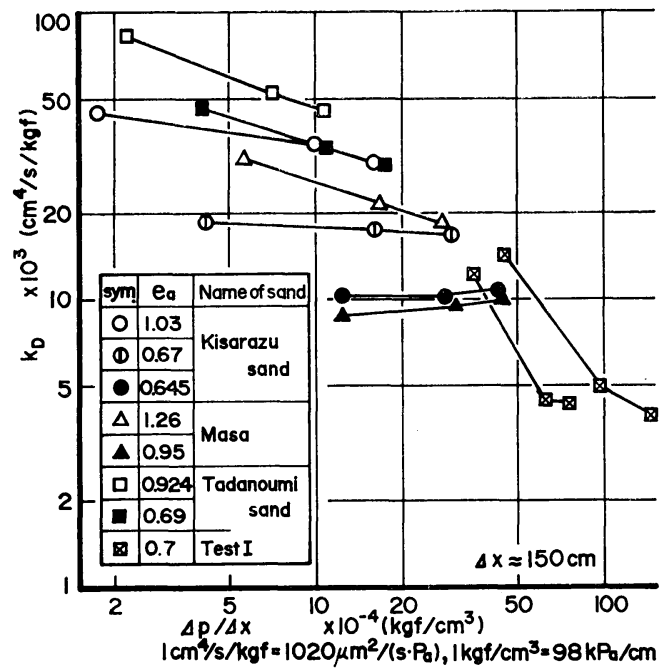

Fig. 24 Permeability coefficient of air $k_{D}$ variation with pressure gradient $\Delta p / \Delta x$.

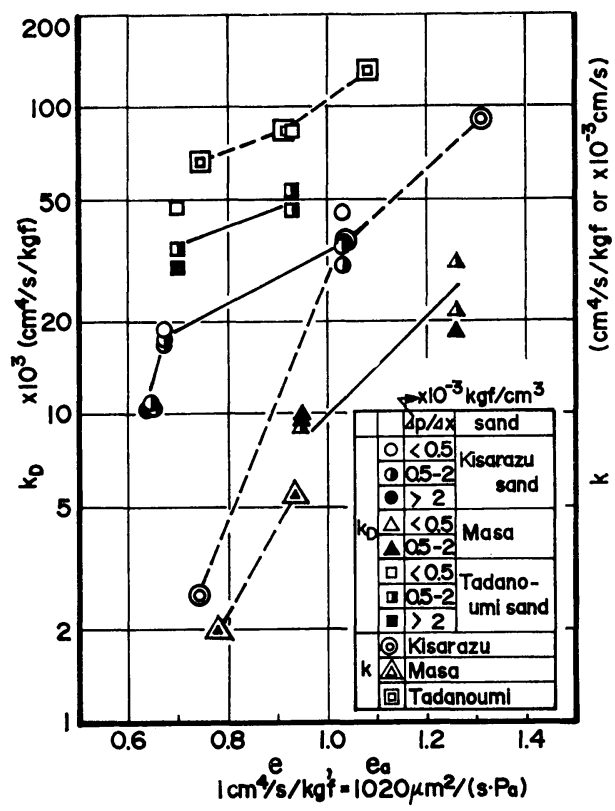

Fig. 25 Relations between permeability coefficient of air $k_{D}$ and air void ratio $e_{a}$ and permeability coefficient of water $k$. 
る透水係数 $k$ の 55 倍といら值よりはるかに大きく, $k$ の数百倍にもなっている.

b) 非定常透気について

実験 I の 非定常透気試験 の 圧力伝達状態を Fig. 26 に示す. 対応した $P_{1}=3.3 \mathrm{kgf} / \mathrm{cm}^{2}(323.4 \mathrm{kPa})$ の定常 透気試験の透気係数 $\left(k_{F}=11890 \mathrm{~cm}^{2} / \mathrm{s}, k_{D}=4900 \mathrm{~cm}^{1} /\right.$ $\left.\mathrm{s} / \mathrm{kgf}\left(4.998 \mathrm{~mm}^{2} /(\mathrm{s} \cdot \mathrm{Pa})\right)\right)$ を用いた理論值と実測值の 比較では, Darcy 則の方が Fick 則より近いが，かなり の相違がある。 そこで，前述の $\Delta p / \Delta x$ により $k_{D}$ が変 わることを考えて， $k_{D}$ がさらに大きな場合の Darcy 則 の理論值とも比較している. 同図から, 初期の圧力勾配 の大きい間は小さな $k_{D}$ を用い，終期に圧力勾配が小さ くなると大きな $k_{D}$ を用いると, 実測に近い理論值が得 られることが想像できる。

なお，Fig. 26 に示した Darcy 則の理論值は，解の 安定性について十分吟味した差分による近似解である.

\section{（4）実施工における砂中の透気について}

実施工で最も一般的な 10 20 m のマンドレル内の砂 柱を圧気圧が $80 \%$ 程度伝達する時間は, 圧力勾配によ る $k_{D}$ の変化を考慮に入れて Darcy 則の式 (13) から求 めると, 粗砂で数十秒から数分, 細砂で数分から数十分 となる．この伝達時間を，圧気をマンドレル上部に与え てからマンドレルを引き抜くまでの実際の時間（数十 秒）と比べると, 引抜き直後の砂の排出が粗砂でよく, 細砂で悪いという現象は十分に説明される．また，細砂 の場合に，内ジェットなどでマンドレル下端付近から圧
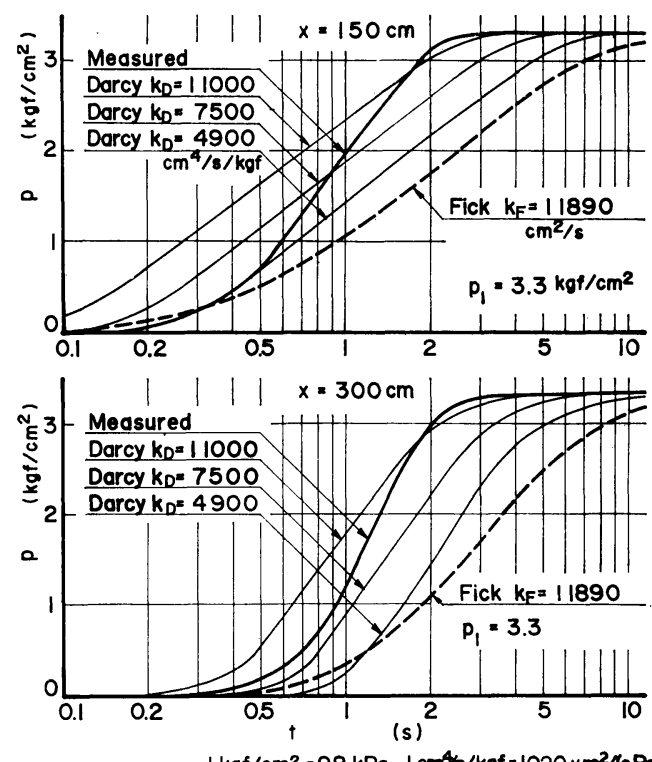

$\left.1 \mathrm{kgf} / \mathrm{cm}^{2}=98 \mathrm{kPa}, \mid \mathrm{cm} / \mathrm{s} / \mathrm{kgf}=1020 \mu \mathrm{m}^{2} / \mathrm{sPa}\right)$

Fig. 26 Air pressure transmission in unsteady seepage flow of air.
気を与えることが効果的なのも当然である.

\section{7. あとがき}

軟弱な粘性土地盤における自然含水状態の砂による砂 杭施工の際の，砂排出の機構は，以下のとおりと推定さ れる。

（1） マンドレル引抜きによって生じた地盤内の空洞 を維持するには，全応力で計算した Rankine 十压程度 の圧力が必要である。

（2）マンドレル内に詰まった砂による鉛直土压は， ほぼ Janssen の式で表わされ，マンドレル底部にはほ とんど作用しない.

（3）マンドレル引抜きの際に併用する圧気が， Darcy 則に従って砂中を透気してマンドレル底部に伝達 される.この空気圧によって空洞が維持される.

（4）この空洞にマンドレルから砂が流下し，排出さ れる。

このような機構から考えると, 自然含水状態の砂によ る粘性土地盤への長尺施工は, 通常の圧気設備（最高で $\left.10 \mathrm{kgf} / \mathrm{cm}^{2}(980 \mathrm{kPa})\right)$ のみで対処すると $60 \sim 70 \mathrm{~m}$ 程度 が限界と考えられ，40〜 $50 \mathrm{~m}$ 程度の実際の施工にも相 当の工夫を要することから，この限界は妥当と考えられ る.これ以上の長尺施工のためには，新しい施工法の開 発が必要である．著者らは，ここに述べた砂排出の機構 をもとに，この開発にも取り組んできたので，別の機会 にこれを発表する予定である。

本研究は著者が不動建設（株）中央研究所在職中に行 ったものである．研究の機会と発表の便宜を与えて下さ った庄野 勝社長をはじめとする同社諸氏に哚甚の謝意 を表する。

\section{参 考 文 献}

1）通産省生活産業局・建設省河川局編：昭和 51 年度砂利採 取業務状況報告書.

2) Barron, R.A. : Consolidation of Fine-grained Soils by Drain Wells, Trans. ASCE, No. 113, pp. $718 \sim 742$, 1948.

3）士質工学会：バーチカルドレーン工法の問題点をさぐる, 土と基礎, Vol. 20, No. 8, pp. 62 74, Aug., 1972.

4）室町忠彦・渡辺 進：王密に上る軟弱地盤の改良効果, 士と基礎, Vol. 20, No. 8, pp. 33〜40, Aug., 1972.

5) Singh, G. and T.N. Hattab : A Laboratory Study of Efficiency of Sand Drains in Relation to Method of Installation and Spacing, Géotechnique, Vol. 29, No. 4, pp. 395 422, 1979.

6）藤森謙一・内田 袈編著：新しい軟弱地盤処理工法，近 代図書, pp. 80 107, pp. 126 151，1969.

7）松尾新一郎編：士質安定工法便覧，日刊工業新聞社，pp. 133 163, pp. 351 384, 1972.

8）榎 明潔：砂杭造成に関する現場測定, 愛媛大学紀要第 III 部工学，第 9 巻，第 4 号，1981 年 2 月. 
9）小川充郎・謝 明潔・西山雅佳：クイの振動貫入と地盤 溞度の関倸, 第 9 回土質工学研究発表会溝演概要集, pp. 913 916, 1974 .

10）榎 明潔・峰洞完治：粘性十地盤に鋼管を振動喵入した

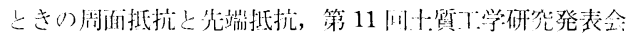
满演概装集，pp. 693 696, 1976.

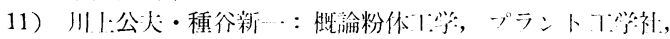
pp. 78 79, 1967.

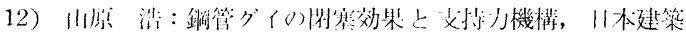

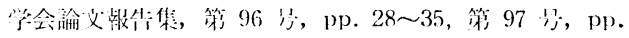
34 41, 1964.

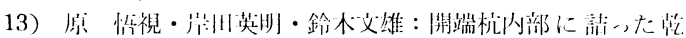

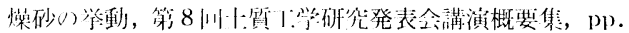
487 $\sim 490,1973$.

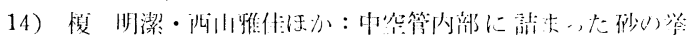

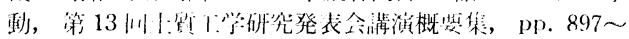
$900,1978$.

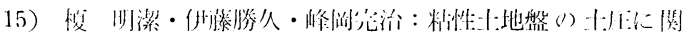

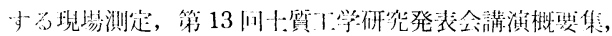
pp. $893 \sim 896,1978$.
16）土質工学会編：土質基礎工学ライブラリー6 鋼グイ一鋼 グイ研究委員会報告一, 上質工学会, pp. 9 11, 1969.

17) Bishop, R.F., R. Hill and N.F. Mott : The Theory of Indentation and Hardness Tests, Proc. Physical Society, Vol. 57, Part 3, pp. 147 159, May, 1945.

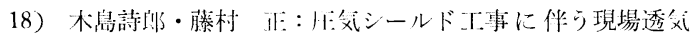
武験について, 1:亡基礎，Vol. 23, No. 4, pp. 19〜27, Apr., 1975.

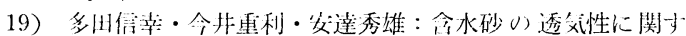

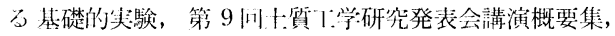
pp. 93 96, 1974 .

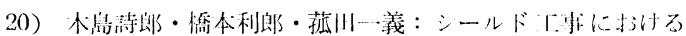

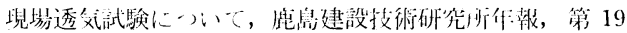
学, 1971.

21) Blight, G.E. : Flow of Air through Soils, Proc. ASCF, Vol. 97, No. SM 4, 1971.

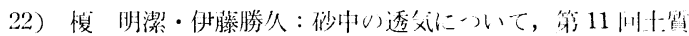

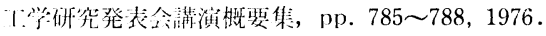

(1980.12.22 · 受付) 